\title{
De l'attractivité à la non durabilité ? Essai sur les stratégies paysannes et pastorales au Lac Horo (Nord Mali)
}

From attractiveness to non sustainability? Essay on farmers and pastoralists strategies around Lake Horo (Northern Mali)

Thomas Hertzog, Amandine Adamczewski et Benoît Lallau

\section{OpenEdition \\ Journals}

Édition électronique

URL : http://journals.openedition.org/economierurale/3535

DOI : 10.4000/economierurale.3535

ISSN : 2105-2581

\section{Éditeur}

Société Française d'Économie Rurale (SFER)

Édition imprimée

Date de publication : 30 juillet 2012

Pagination : 125-144

ISSN : 0013-0559

Référence électronique

Thomas Hertzog, Amandine Adamczewski et Benoît Lallau, « De l'attractivité à la non durabilité ? Essai sur les stratégies paysannes et pastorales au Lac Horo (Nord Mali) », Économie rurale [En ligne], 330-331 | juillet-septembre 2012, mis en ligne le 30 juillet 2014, consulté le 08 mai 2019. URL : http:// journals.openedition.org/economierurale/3535; DOI : 10.4000/economierurale.3535 
